\title{
Paving the Way for Personalised Behaviourally based Prevention of Obesity: Systematic Search of the Literature
}

\author{
Kristina Fišter, Sivije Vuletić and Josipa Kern \\ University of Zagreb, School of Medicine, »Andrija Štampar« School of Public Health, Zagreb, Croatia
}

\begin{abstract}
A B S T R A C T
We have identified in the literature variants in 64 genes that may be involved in gene-obesity-behaviour interactions. Personalisation of behaviourally based preventive approaches against obesity seems feasible, however obesity genomics is still in the discovery phase of translational research and abundant replication studies are needed before these largely pioneering findings can be extended to practice and population impact. Automation of search algorithms and development of more efficient tools for knowledge synthesis of genomic research into gene-obesity-behaviour interactions might facilitate the advent of widely available personalised prevention approaches. Our future efforts shall therefore concentrate on developing such tools, as well as a research repository dedicated to the use of public health genomics for obesity control.
\end{abstract} search

Key words: obesity, genomics, single nucleotide polymorphism, health behaviour, public health, translational re-

\section{Introduction}

Efforts aimed at primary and secondary prevention of cardiovascular disease, the major killer of contemporary adult populations ${ }^{1-3}$, largely rely on modification of risk behaviours related to smoking, physical activity, dietary intake, and alcohol consumption ${ }^{4,5}$. Control of obesity and hypertension, the interim risk states between health and disease, constitute another large part of preventive ventures.

In the public health that increasingly turns its attention toward genomics, the major challenge is to understand the role of genetic variants in susceptibility to chronic diseases and associated risk factors ${ }^{6}$. This has required characterising the nature of gene variation, assembling an extensive catalogue of single nucleotide polymorphisms (single base-pair mutations that occur at a specific site in the DNA sequence, SNPs) in candidate genes, and performing association studies and other gene mapping studies.

A step further, we need to incorporate findings from genomics into clinical and public health interventions. Beyond associations studied in classical epidemiology those of behavioural risk factors and obesity phenotype ${ }^{7}$
- as well as beyond the major genes that play a deciding role in monogenic obesity, such as is leptin deficiency for example, we were interested in SNPs - primary genetic information and primary variants where the genetic predisposition could be discovered - and their role in developing common obesity ${ }^{8}$. No single SNP will cause a complex trait; however, in a gene-environment interaction, a combination of variants exposed to what is often called 'obesogenic' environment will increase the relative risk that an individual develops the trait.

The extent to which this process is mediated by associations between particular SNPs and behavioural risk factors for overweight or obesity may determine opportunities for novel, personalised preventive interventions. Currently most effective interventions combine nutrition education and exercise counselling with behavioural strategies to improve a person's ability to lose weight $t^{9,10}$. In other words, current interventions require that all people work on both sides of the intake-expenditure energy equation. Such one-size-fits-all approach has not reaped much success in controlling the burden of obesity. Alternatively, personalised prevention strategies might 
be able to identify people who are more likely to benefit from focusing on one or the other side of the energy equation, as well as people who are more likely to lose weight in response to certain macronutrient diet compositions (e.g., low-fat or low-carbohydrate diet).

\section{Objectives}

In the informational abundance of over 10 million human SNPs that are currently listed in publicly accessible databases $^{11}$, we aimed to identify SNPs that are linked both with increased body weight and behavioural risk factors for this trait, thus holding promise for future design of personalised behaviourally based preventive interventions to reduce obesity.

\section{Methods}

In the initial search, the results of which have previously been communicated ${ }^{12}$, we searched the Cochrane Database of Systematic Reviews, MEDLINE, INSPEC, Current Contents, and Cochrane Controlled Trials Register for abstracts of surveys published to December 2008 in any language, which had examined the associations between any SNPs and behaviours implicated in the aetiology of human obesity, namely physical activity, smoking, diet, alcohol consumption, and psychological stress. Two researchers checked all abstracts for eligibility and we included in both the previous and the current report only those articles that found significant associations between identified SNPs and one or more behaviours of interest. Animal studies were excluded.
For this report, we expanded the search to December 2009 using HuGE Navigator, an integrated knowledge base on human genome epidemiology ${ }^{13}$. HuGE Navigator is updated weekly from PubMed by means of an automatic literature screening program. A genetic epidemiologist selects abstracts that meet inclusion criteria and indexes them by gene, category, and study type. We searched HuGE Navigator's Phenopedia for gene-environment interaction articles with obesity and behaviours of interest as search terms.

\section{Results}

Our initial search returned 77 abstracts of which 18 were deemed eligible for inclusion (Tables 1 and 2). The HuGE Navigator search returned all but one abstracts identified in the initial search ${ }^{14}$, as well as 45 additional articles eligible for inclusion (Table 3). In total, gene-obesity-behaviour interactions were reported for 46 genes.

In one article, where 26 SNPs on the fat mass and obesity associated (FTO) gene were found to be associated with body mass index (BMI), two variants - rs1477196 and rs1861868 - were only associated with obesity in people with low levels of physical activity. No association between these two variants and BMI was found among people with above-average physical activity scores.

Another article indicated that alcohol consumption may play a protective mediating role in one variant's impact on glucose metabolism: in men, carriers of $14672 \mathrm{C}>\mathrm{G}$ in the promoter region of hormone-sensitive lipase locus (LIPE) who did not drink alcohol had higher glucose levels

TABLE 1

SINGLE NUCLEOTIDE POLYMORPHISMS (SNPs) (IDENTIFIED IN THE INITIAL SEARCH) WHICH SEEM TO BE INVOLVED IN THE PATHOPHYSIOLOGY OF OBESITY AND LINKED WITH RISK BEHAVIOURS (PHYSICAL ACTIVITY, ALCOHOL CONSUMPTION, AND CONTROL OF APPETITE)

\begin{tabular}{|c|c|c|}
\hline People & SNP & Phenotype associations \\
\hline $\begin{array}{l}704 \text { healthy Old order Amish people [Arch } \\
\text { Intern Med } 168 \text { (2008), 1791-7] }\end{array}$ & $\begin{array}{l}\text { rs1477196 and rs1861868 on fat mass and } \\
\text { obesity associated (FTO) gene }\end{array}$ & $\begin{array}{l}\text { Associated with body mass index in people } \\
\text { with low physical activity scores (adjusted } \\
\text { for age and sex) }\end{array}$ \\
\hline $\begin{array}{l}\text { Population of mostly overweight and } \\
\text { obese } 373 \text { men and } 361 \text { woman [Clin } \\
\text { Genet } 65 \text { (2004), 93-100] }\end{array}$ & $\begin{array}{l}14672 \mathrm{C}>\mathrm{G} \text { in promoter region of } \\
\text { hormone-sensitive lipase locus (LIPE) } \\
\text { gene }\end{array}$ & $\begin{array}{l}\text { In women, LIPE } 14672 \mathrm{G} \text { was associated } \\
\text { with significantly higher total cholesterol, } \\
\text { LDL-cholesterol and apoE; in men, } \\
\text { carriers who don't drink alcohol have } \\
\text { higher glucose levels than non-carriers }\end{array}$ \\
\hline $\begin{array}{l}\text { 1,058 cases and } 1,102 \text { controls [Cancer } \\
\text { Epidemiol Biomarkers Prev } 15 \text { (2006), } \\
811-5]\end{array}$ & $\begin{array}{l}\text { Ser(326)Cys and } 11657 \mathrm{~A} / \mathrm{G} \text { in } \\
\text { Oxodeoxyguanosine (OGG1) gene }\end{array}$ & $\begin{array}{l}\text { Ser }(326) \text { Cys associated with breast cancer } \\
\text { risk among moderate alcohol drinkers } \\
11657 \mathrm{~A} / \mathrm{G} \text { associated with } \mathrm{BMI}>25\end{array}$ \\
\hline $\begin{array}{l}\text { First: } 93 \text { cases } 469 \text { controls; Second: } 564 \\
\text { cases } 562 \text { controls; Third: } 394 \text { cases } 958 \\
\text { controls [Human Molecular Genetics } 16 \\
(2007), 3017-26]\end{array}$ & $\begin{array}{l}\text { rs2293855 in myotublarin-related protein } \\
9 \text { (MTMR9) gene }\end{array}$ & $\begin{array}{l}\text { MTMR9 mRNA levels increased after } \\
\text { fasting and decreased after high-fat diet - } \\
\text { regulation of hypothalamic neuropeptides } \\
\text { and thus possibly control of appetite }\end{array}$ \\
\hline $\begin{array}{l}\text { Sample of } 218 \text { obese Finnish sibling pairs; } \\
\text { independent samples of } 837 \text { cases and } 968 \\
\text { controls [J Clin Invest } 112 \text { (2003), 1762-72] }\end{array}$ & SNP haplotype of the SLC6A14 gene & $\begin{array}{l}\text { Evidence of linkage emerged mainly from the } \\
\text { obese male sib pairs, suggesting a gender- } \\
\text { specific effect for the underlying gene }\end{array}$ \\
\hline $\begin{array}{l}2455 \text { white female twins [Obesity (Silver } \\
\text { Spring) } 15 \text { (2007), 5-9] }\end{array}$ & $\begin{array}{l}\text { A tagging SNP/tSNP, Ala484Thr } \\
\text { (rs7498665) in the region encompassing } \\
\text { the human SH2-B gene }\end{array}$ & $\begin{array}{l}\text { Ala484Thr (minor allele frequency } 0.38 \text { ) } \\
\text { was associated with serum leptin, total } \\
\text { fat, waist circumference, and body weight }\end{array}$ \\
\hline
\end{tabular}


TABLE 2

SINGLE NUCLEOTIDE POLYMORPHISMS (SNPs) (IDENTIFIED IN THE INITIAL SEARCH) WHICH SEEM TO BE INVOLVED IN THE PATHOPHYSIOLOGY OF OBESITY AND LINKED WITH RISK BEHAVIOURS (DIET)

\begin{tabular}{|c|c|c|}
\hline People & SNP & Phenotype associations \\
\hline $\begin{array}{l}1680 \text { middle-aged Dutch women [Plos } \\
\text { ONE } 3(2008), \text { e1405] }\end{array}$ & $\begin{array}{l}\text { rs } 2272382, \mathrm{rs} 227283, \text { and } \mathrm{rs} 1528133 \\
\text { in the TUB gene }\end{array}$ & $\begin{array}{l}\text { Eating behaviour associated with body } \\
\text { composition and macronutrient intake }\end{array}$ \\
\hline $\begin{array}{l}451 \text { obese participants [Horm Metab Res } \\
39 \text { (2007), 395-7] }\end{array}$ & $\begin{array}{l}\text { P129T polymorphism in fatty acid } \\
\text { amide hydrolase (member of the } \\
\text { endocannabinoid (ECS) system) }\end{array}$ & $\begin{array}{l}\text { After six weeks of low fat diet, carriers had a } \\
\text { significantly greater decrease in total cholesterol } \\
\text { and triglycerides, compared with wild type }\end{array}$ \\
\hline
\end{tabular}

1,073 men and 1,207 women in the

Framingham offspring study [J Mol Med APOA5-1131T $>$ C polymorphism 82 (2007), 119-28]

\begin{tabular}{|c|c|c|}
\hline $\begin{array}{l}214 \text { overweight women from Korea } \\
\text { [Metabolism } 55 \text { (2006), 578-86] }\end{array}$ & $\begin{array}{l}\text { Haplotype } 1 \text { (ht1) (CGTACC) on the } \\
\text { uncoupling protein } 3 \text { (UCP-3) gene }\end{array}$ & $\begin{array}{l}\text { After one month of low-energy diet, associated } \\
\text { with greater reduction in body weight, BMI, } \\
\text { body fat mass; but not with body fat free mass }\end{array}$ \\
\hline $\begin{array}{l}453 \text { overweight women from Korea } \\
\text { [Biochem Biophys Res Commun } 335 \\
(2005), 624-30 \text { ] }\end{array}$ & $\begin{array}{l}\text { A-3826G, A-1766G, and Ala64Thr } \\
(\mathrm{G}+1068 \mathrm{~A}) \text { on UCP-1 gene }\end{array}$ & $\begin{array}{l}\text { After one month of very low calorie diet, } \\
\text { ht3[GAG] associated with faster reduction in } \\
\text { waist-to-hip ratio and body fat mass }\end{array}$ \\
\hline $\begin{array}{l}249 \text { non-diabetic overweight or obese } \\
\text { people from Korea [Int J Obes (Lond) } 30 \\
(2006), 1702-8 \text { ] }\end{array}$ & $\begin{array}{l}276 \mathrm{G}>\mathrm{T} \text { at adiponectin (ADIPOQ) } \\
\text { gene }\end{array}$ & Modifies response to low calorie diet \\
\hline $\begin{array}{l}300 \text { patients randomised to two diet } \\
\text { groups over } 3 \text { to } 12 \text { months [Proc Nutr } \\
\text { Soc } 61(2002), 427-34 \text { ] }\end{array}$ & Various SNPs on several genes & $\begin{array}{l}\text { Interactions with metabolic response to } \\
\text { Mediterranean/low fat diet or Western type diet }\end{array}$ \\
\hline $\begin{array}{l}30 \text { men and } 29 \text { women [J Nutr } 138 \\
(2008), 1609-14]\end{array}$ & $-11377 \mathrm{C}>\mathrm{G}$ at the adiponectin gene & $\begin{array}{l}\mathrm{C} / \mathrm{C} \text { homozygous men had a greater decrease in } \\
\text { the steady-state plasma glucose concentrations } \\
\text { when changing from SFA-rich to MUFA-rich diet }\end{array}$ \\
\hline $\begin{array}{l}458 \text { overweight women [Biochem } \\
\text { Biophys Res Commun } 359 \text { (2007), } \\
451-6]\end{array}$ & $\begin{array}{l}10 \text { polymorphisms in uncoupling } \\
\text { protein UCP-2 and UCP-3 }\end{array}$ & $\begin{array}{l}\text { Modified response to a one-month very-low } \\
\text { calorie diet regimen }\end{array}$ \\
\hline $\begin{array}{l}651 \text { people of Japanese ethnicity ( } 274 \\
\text { Hawaiian Americans and } 377 \text { native } \\
\text { Japanese people) [Obesity (Silver } \\
\text { Spring) } 16 \text { (2008), 1463-6] }\end{array}$ & $\begin{array}{l}\text { rs } 235326 \text { in the gene encoding human } \\
\text { integrin beta } 2 \text { subunit (ITGB2) }\end{array}$ & $\begin{array}{l}\text { In Hawaiian Americans (whose diet has become } \\
\text { »westernized«): compared with C carriers, TT } \\
\text { homozygotes were } 3.29 \text {-times more likely to be } \\
\text { obese; no such association was found among } \\
\text { people living in Japan }\end{array}$ \\
\hline $\begin{array}{l}1,357 \text { obese adults and children from } \\
\text { France [Obes Res } 11 \text { (2003), 1163-7] }\end{array}$ & $\begin{array}{l}\text { 79-bp T-to-C on the } 3 \text { ' region of the } \\
\text { diacylglycerol acyltransferase (DGAT) } \\
\text { encoding gene }\end{array}$ & $\begin{array}{l}\text { Not associated with obesity-related phenotypes } \\
\text { in this study, although a positive association has } \\
\text { been reported in Turkish women }\end{array}$ \\
\hline $\begin{array}{l}\text { People living in affluent societies in } \\
\text { several parts of Asia and Pacific islands } \\
\text { [Biochem Biophys Res Commun } 295 \\
(2002), 207-22]\end{array}$ & $\begin{array}{l}\text { Thrifty SNPs encoding FABP", MTP, } \\
\text { CAL10, beta 3AR, apo-E, UCP2, } \\
\text { UCP3-p, PPARgama2 and LEPR }\end{array}$ & $\begin{array}{l}\text { Differences in these SNPs between Mongoloids } \\
\text { and Caucasoids may have been caused by } \\
\text { natural selection depending on the types of } \\
\text { agricultures practiced in different regions and } \\
\text { consequently diet }\end{array}$ \\
\hline
\end{tabular}

than non-carriers, but there were no differences among people who do drink alcohol. In the oxodeoxyguanosine (OGG1) gene, variant Ser(326)Cys was found to be associated with the risk for breast cancer, but only among moderate alcohol drinkers, while another variant in the same gene - 11657A/G - was associated with increased body weight.

Variants in the myotublarin-related protein 9 (MTMR9) gene, SLC6A14 gene, and SH2-B gene showed the potential to affect control of appetite.

A number of articles implicated various SNPs, located on several genes, in changing carriers' response to diet. In the TUB gene, for example, AG heterozygote and AA homozygote of the rs2272382 derived less energy from fat, and both were associated with increased energy intake from carbohydrates. Both rs22728133 and rs1528133 were also associated with higher glycaemic load in the diet, which was higher than glycaemic load among the wild types. Concerning the APO gene, among people with APOA5-1131T (major allele) the BMI increased with higher fat intake; however, in APOA5-1131C (minor allele) no increase was seen in BMI with increased fat consumption. Carriers of APOA5-1131C minor allele had a lower risk for overweight and obesity, but not when fat intake was low.

UCP-3 was exposed as an anti-thrifty gene that dissipates energy as heat and prevents obesity, while variants in the adiponectin gene had an impact on insulin resis- 
TABLE 3

SINGLE NUCLEOTIDE POLYMORPHISMS (SNPs) (IDENTIFIED IN THE HUGENAVIGATOR SEARCH) WHICH SEEM TO BE INVOLVED IN THE PATHOPHYSIOLOGY OF OBESITY AND LINKED WITH RISK BEHAVIOURS (PHYSICAL ACTIVITY, DIET, AND MIXED INTERVENTIONS)

\begin{tabular}{lll}
\hline People & SNP & Phenotype associations \\
\hline Physical activity &
\end{tabular}

Physical activity

604 Caucasian individuals (aged 40-65 yr) [J Clin Endocrinol Metab 86 (2001) $5881-7]$
Gly16Arg in the beta $(2$ - adrenergic receptor (BAR-2) gene
Women carriers of the Arg16Arg genotype had lower fasting plasma NEFAs (nonesterified fatty acid) $(\mathrm{P}<0.01)$ and greater

suppression of NEFAs $(P<0.01)$ after an oral glucose load than women bearing the Gly16 allele. After adjustment for confounding by age, smoking, and BMI, the effect of the Arg16Arg genotype on the suppression of NEFA levels was modified by physical activity level ( $\mathrm{P}$ for interaction $<0.05$ )

FTO variant rs1121980 was genotyped in 20,374 participants (39-79 y of age) from the EPIC and Nutrition-Norfolk Study [Am J Clin Nutr 90 (2009) 425-8]

Two European prospective

population-based cohorts of 4,762

rs1421085 and Finnish adolescents (NFBC 1986) and rs17782313 in FTO and MC4R are additive, predictive of obesity, and may be influenced 3,167 French adults (D.E.S.I.R.) [J Mol MC4R Med 87 (2009) 537-46]

862 subjects from the Quebec Family Study [Hum Genomics 3 (2009) 157-68]
LIPE C-60G polymorphism
Physical activity attenuates the effect of the FTO rs1121980 genotype on BMI and WC
737 Korean children and 732 adults [Obesity (Silver Spring) 17 (2009) 355-62]

1306 participants enrolled in the JingNing population study [ $\mathrm{J}$ Hypertens 26 (2008) 2161-7]

3,856 type 2 diabetic case subjects and 4,861 normal glucose-tolerant control subjects [Diabetes 57 (2008) 95-101]

Sample of 14,716 African Americans (AAs) and whites from the ARIC [Int J Obes (Lond) 31 (2007) 919-26]

A population-based study comprising 899 women and 902 men aged between 30 and 75 years in Vara, Sweden [Diabetologia 49 (2006) 496-500]

157 obese subjects $(\mathrm{BMI}>$ or $=30)$ and 150 controls $(\mathrm{BMI}<25)$ [Ann Nutr Metab 49 (2005) 183-8]

UCP3 $-55 \mathrm{C}>\mathrm{T}$ polymorphism a55Val, and UCP3-55C $>$ T

ADRA2B D/I polymorphism
(UCP) 2 and UCP3; UCP2-866G > A,UCP2A

rs9939609 in the FTO

GNB3 $825 \mathrm{C}>\mathrm{T}$ in the GNB3 gene

PPARGC1A GLy482Ser physically inactive elderly male subjects. Whenever possible, the level of physical activity should be addressed in future studies on disease risk associated with PPARGC1A Gly482Ser

UCP3 -55C $>$ T polymorphism carriers have apparently a lower risk of obesity when taking into consideration recreational energy expenditure. Interestingly, this inverse beneficial association may only occur in people with a high level of physical activity
Diet

108 subjects who underwent an 8-day modified medical fasting treatment [Ann Nutr Metab 54 (2009) 184-8]

180 Spanish volunteers (BMI:

$31.4+/-3.2 \mathrm{~kg} / \mathrm{m}(2)$ [Horm Metab Res 41 (2009) 55-61]
GNB3 C825T

polymorphism
Pronounced mental discomfort during fasting in $825 \mathrm{~T}$ allele carriers might partly explain their increased risk for obesity rs17300539 (11391 G/A) low-calorie diet, and the effect is particularly evident 32-60

in the adiponectin gene weeks after the dietary intervention, when improvement in GG subjects had disappeared

Detailed dietary report information on FTO variation and dietary intake $[$ Am rs9939609 in the FTO J Clin Nutr 88 (2008) 971-8]
Persons carrying minor variants at rs9939609 were consuming more fat and total energy than were those not carrying such variants 
Cohort of 1,721 Caucasian men and women with a BMI of $25 \mathrm{~kg} / \mathrm{m}(2)$ or more [Mol Genet Metab 95 (2008) 188-91]

Population-based sample of Caribbean-origin Hispanics ( $\mathrm{n}=920$, aged 45-74 y) [Nutr 138 (2008) 1852-8]
CB1, NPY, 420C $>$ G polymorphisms in the resistin gene rs894160 (11482G>A) in the PLIN gene

\begin{tabular}{ll}
\hline 204 obese people [Diabetes Res Clin & FABP2 \\
Pract 82 (2008) 113-8] & $\begin{array}{l}\text { Lys656Asn } \\
\text { polymorphism in the } \\
\text { LEPR gene }\end{array}$ \\
\begin{tabular}{l} 
(2008) $209-14]$ \\
\hline
\end{tabular}
\end{tabular}

107 obese people (body mass index $>30$ ) [Horm Metab Res 40 (2008) $214-8]$

29 obese and 45 non-obese people 18-40 years old [Behav Neurosci 121 (2007) 877-86]

Healthy Japanese men, $\mathrm{n}=295[\mathrm{~J}$ Epidemiol 15 (2005) 203-10] ADRB3 Trp64Arg the UCP3 gene
Genetic polymorphisms associated with obesity may become relevant only under the condition of a low calorie diet

In subjects with higher complex carbohydrate intake, the minor allele was protective against obesity, whereas in subjects with lower carbohydrate intake, the minor allele was associated with increased obesity

Weight loss is associated with different changes, depending on the FABP genotype with both hypocaloric diets tested

In wild type patients, the changes in serum leptin concentration due to 2 months' intervention with low fat are higher than with a low carbohydrate diet

Patients with -55CC genotype have a significant decrease in leptin, interleukin 6, BMI, weight, fat mass, systolic blood -55CT polymorphism of pressure, LDL cholesterol, waist circumference, waist-to-hip ratio weight, fat mass, and systolic blood pressure, in response to a hypocaloric diet

Energy intake was greater for individuals high in food reinforcement and greatest in those high in food reinforcement with the TaqI A1 allele

High energy intake interacts with the polymorphism and leads to a significant increase in risk of obesity. The Trp64Arg polymorphism of ADRB3 warrants consideration, along with other polymorphisms involved in the development of obesity, for tailor-made prevention of obesity

Asp358Ala (T/G)

Indices of obesity might be modulated by an interaction 85 healthy Japanese men [Metabolism polymorphism in the 56 (2007) 925-30] interleukin 6 receptor (IL6R) gene

Two PPARgamma

Selected obese women - diet responsive $(\mathrm{n}=74)$ and diet-resistant $(\mathrm{n}=67)$ [Obesity (Silver Spring) 15 (2007) 1068-75] SNPs, Pro(12)Ala and C1431T, and eight polymorphisms across the ACSL5 gene

67 volunteers in the 10 week low-energy diet program, followed by a 1-year weight-loss maintenance [ $\mathrm{Br} \mathrm{J}$ Nutr 96 (2006) 965-72]

$-174 \mathrm{G}>\mathrm{C}$ from IL-6 and PPAR-gamma2 Pro12Ala variants

351 French-Canadians, 40 overweight subjects and 4 controls [ $\mathrm{J}$ Mol Med 85 (2007) 129-37]

549 adult obese women recruited from eight European centres [Eur J Nutr 45 (2006) 454-62]

42 polymorphisms in 26
candidate genes candidate genes

Dietary energy intake modifies the association between gene and waist circumference

The PPARgamma Pro(12)Ala single nucleotide polymorphism was associated with diet resistance (odds ratio $=3.48,95 \%$ confidence interval $=1.41$ to $8.56, \mathrm{p}=0.03$ ) after the first 6 weeks of a $900-k c a l$ formula diet (low calorie)

The present study demonstrates that the $\mathrm{C}$ allele of the $-174 \mathrm{G}>\mathrm{C}$ polymorphism gives protection against regain of weight lost. Moreover, the presence of the Ala allele of the PPARgamma-2 together with the $\mathrm{C}$ allele strengthens this protection between $\mathrm{CPT} 1$ variants and fat intake

The test of interaction between fibre intake and the $-514 \mathrm{C}>$ $\mathrm{T}$ polymorphism of the hepatic lipase gene (LIPC) was 6 significant; the $-11377 \mathrm{G}>\mathrm{C}$ polymorphism of the adiponectin gene $(\mathrm{ADIPOQ})$ and the $-681 \mathrm{C}>\mathrm{G}$ polymorphism of the PPARG3 gene might interact with the percentage of energy derived from fat in the diet, for the development of obesity Intake of dietary fats and saturated fatty acids should be controlled in Pro12Pro/Gln27Gln and Pro12Pro/Gln27Glu, and complex CHO and MUFA in Pro12Pro/Glu27Glu. In Pro12Ala/Gln27Glu, AGPI intake can result in greater body weight loss

PPARgamma2 and and long-term hypocaloric diets, varying in macronutrients [Nutr Hosp 21 (2006) 317-31]

beta2 - adrenergic receptor genes rs2959272, rs1386835, rs709158, rs1175540,

14-week calorie restriction diet in 95 middle-aged, Japanese women (BMI $>/=25 \mathrm{~kg} / \mathrm{m} 2$ ) [Obesity (Silver Spring) 17 (2009) 1924-31] rs1175544, and rs1797912 in the PPARG gene
Body weight decreased significantly $(-7.7+/-3.1 \mathrm{~kg}$; $-11.3+/-4.4 \%$ ). All six SNPs were found to be associated with the weight reduction, with rs1175544 having the strongest association 


\begin{tabular}{|c|c|c|}
\hline $\begin{array}{l}\text { Non-diabetic/overweight-obese Koreans } \\
(\mathrm{n}=177) \text { [J Int Obes (Lond) } 30 \text { (2006) } \\
1601-8]\end{array}$ & $\begin{array}{l}6209 \mathrm{~T}>\mathrm{C}, 10076 \mathrm{C}>\mathrm{G}, \\
10171 \mathrm{~A}>\mathrm{T}, 11482 \mathrm{G}>\mathrm{A}, \\
13042 \mathrm{~A}>\mathrm{G}, 13048 \mathrm{C}>\mathrm{T} \\
\text { and } 14995 \mathrm{~A}>\mathrm{T} \text { in } \\
\text { perilipin }(\mathrm{PLIN})-\mathrm{a} \\
\text { class of protein-coating } \\
\text { lipid droplets in } \\
\text { adipocytes }\end{array}$ & $\begin{array}{l}\text { Subjects with nCA/nCA haplotypes at } \mathrm{SNPs} \\
10076 \mathrm{C}>\mathrm{G} / 10171 \mathrm{~A}>\mathrm{T} \text { showed greater reduction in FFA levels } \\
\text { than those with } \mathrm{CA} / \mathrm{CA} \text { haplotype after a } 12 \text {-week calorie } \\
\text { restriction }(-300 \mathrm{kcal} / \text { day) program }\end{array}$ \\
\hline $\begin{array}{l}606 \text { hyperlipaemic and overweight men } \\
\text { [Clin Genet } 68 \text { (2005) 152-4] }\end{array}$ & $\begin{array}{l}\text { Several SNPs (wildtype } \\
\text { and carriers of the } \\
-1131 \mathrm{~T}>\mathrm{C} \\
\text { polymorphism) in the } \\
\text { Apolipoprotein A5 gene }\end{array}$ & $\begin{array}{l}\text { Reduction of BMI was significantly higher in } \mathrm{C} \text { allele carriers } \\
\text { after a short-term dietary fat restriction }\end{array}$ \\
\hline
\end{tabular}

150 obese patients at baseline and 48 patients who completed the dietary follow-up; randomised trial with 1-year PLIN 11482G>A low energy diet [ $\mathrm{J}$ Clin Endocrinol polymorphism Metab 90 (2005) 5121-6]

PLIN11482A carriers were resistant to weight loss

224 overweight-obese subjects with coronary artery disease (CAD) or metabolic syndrome [Int J Obes Relat Metab Disord 28 (2004) 434-41]

\section{Participants subdivided} into 4 categories: (TT-CC, $\mathrm{n}=73$ ); (TT-CT/TT, $\mathrm{n}=90$ ); (TA/AA-CC, $\mathrm{n}=29$ ); (TA/AA-CT/TT, $\mathrm{n}=32$ ) according to status on beta3-AR and UCP3
After a $-300 \mathrm{kcal} /$ day mild weight reduction program for 12 weeks, the beneficial effects on body fat distribution and glycemic control were greatest in the 'wild-type' group and smallest in 'both variants' group. In addition, these effects were less beneficial in carriers with beta3-AR gene variant than with UCP3 gene promoter variant

EPIC-Heidelberg: 154 subjects with a body mass index $>35 \mathrm{~kg} / \mathrm{m}(2)$ and 154 PPARA, PPARG2, age- and sex-matched normal-weight controls; dietary fatty acid intake assessed by food frequency questionnaire [Eur J Nutr 41 (2002) UCP1, UCP2, UCP3, BAR-2, APM1, leptin SORBS1, HSL, and Gene-diet interactions suggest that the allelic variants of candidate genes (leptin, TNFA, PPARG2) might strongly affect diet-related obesity risk 210-21]

61 women with the APOE $2 / 3$ and APOE 3/3 genotype (APOE4-) and 18 women with the APOE $3 / 4$ genotype (APOE4+) [Metabolism 51 (2002) TNFA

Apolipoprotein E (APOE)

It may be prudent to genotype older women before initiating low-fat diet therapy, as those with the APOE4 allele benefit the most, while the lipid profile could worsen in women without the APOE4 allele after a low-fat, low-cholesterol diet over 10 weeks

The Arg allele carriers of the Lys109Arg LEPR gene polymorphism were associated with an increased
proinflammatory state and stress condition at baseline. These obesity-related markers were importantly decreased after an 8-week energy-restricted (hypocaloric) diet $(-30 \% \mathrm{E}) \operatorname{diet}$

170 Caucasian participants [Arch Med Lys109Arg in the lepti Res 40 (2009) 306-10] receptor gene (LEPR)

Low-fat vegan diet or a diet for 74 weeks among 93 adults with type 2 diabetes [Nutrition 25 (2009) 58-65]

$\mathrm{A} 1 \mathrm{~A} 1$ and $\mathrm{A} 1 \mathrm{~A} 2$ in the D2 dopamine receptor Among whites in the vegan group, $\mathrm{A} 1(+)$ individuals reduced fat intake $(\mathrm{P}=0.04)$ and $\mathrm{A} 1 \mathrm{c}(\mathrm{P}=0.01)$ significantly less than did A1(-) individuals

Carriers of the T variant experienced decreases in BMI, weight,

131 obese individuals (body mass index -55CT polymorphism in >30) [Horm Metab Res 41 (2009) 62-6] the UCP3 gene

and fat mass on two different hypocaloric diets, without statistical changes in biochemical parameters

363 subjects with impaired fasting glucose (IFG) or newly diagnosed type

2 diabetes followed a dietary

intervention and regular walking for $12 \mathrm{ADIPOQ}$

weeks without any medication

[Diabetes Care 32 (2009) 552-8]

ADIPOQ genetic variants can affect circulating adiponectin levels and insulin resistance indexes in subjects with IFG or newly diagnosed type 2 diabetes in response to dietary intervention

Mixed interventions rs659366, rs653529,

507 overweight individuals randomised rs15763, and Genetic variation in the UCP2-UCP3 gene cluster may act as a to intensified diet and physical activity group or a conventional care control

rs1726745; rs659366-G, modifier increasing serum lipid levels and indices of abdomina
rs653529-A, rs15763-G obesity, and may thereby also contribute to the metabolic group [BMC Med Genet 10 (2009) 94] and rs1726745-A in the aberrations observed in obesity and type 2 diabetes UCP2 and UCP3 
120 obese Japanese women and 146 healthy age-matched controls; diet and exercise therapy for 6 months [Metabolism 55 (2006) 819-24]

67 obese (body mass index $>30$ ) nondiabetic outpatients [Arch
Angiotensinogen (AGT) Met235Thr polymorphism (M235T)

Lys656Asn polymorphism in the leptin receptor gene
The T/T genotype of the AGT M235T gene polymorphism was positively related to visceral obesity and hyperinsulinemia 37 (2006) 854-9]
69 obese (body mass index $>30$ ) nondiabetic outpatients [Ann Nutr Metab 50 (2006) 354-60]
Patients with Asn656 allele of LEPR gene have a different response to a lifestyle modification program than wild-type patients, and Lys656Lys patients have a significant decrease in weight, BMI, fat mass, waist circumference, systolic blood pressure and leptin levels

Carriers of the Thr54 allele have a different response to a lifestyle modification (Mediterranean hypocaloric diet and Thr54 polymorphism in exercise) than wild-type obese subjects, with a significant the FABP2 gene decrease of systolic blood pressure and glucose levels in Thr54 carriers and a significant decrease in fat mass, low-density lipoprotein cholesterol, and leptin in wild-type patients

76 perimenopausal women with no clinical symptoms; 3-month behavioural intervention study using a the beta(3)-adrenergic combination of diet and exercise programs [Int J Obes Relat Metab Disord 27 (2003) 1028-36]

69 obese non diabetic outpatients [Med Clin (Barc) 129 (2007) 401-4]

Randomised controlled trial of 3,548 high-risk individuals from 27 participating centres throughout the USA [Diabetologia 51 (2008) 2214-23]

151 subjects participating in a lifestyle intervention program to prevent diabetes [Exp Clin Endocrinol Diabetes 117 (2009) 194-7]
G308A variant in the tumor necrosis factor alpha (TNF-alpha) gene

rs9939609 in the FTO gene and rs7566605 in the INSIG2 gene receptor (beta(3)AR) gene

The mutation is associated with difficulty in losing weight through behavioural intervention, although it is not related to obesity-related phenotypes and resting energy expenditure before the intervention

Carries of G308G variant of TNF-alpha gene have a better metabolic response (to a 3-month of lifestyle modification program that included a hypocaloric diet 1,520 kcal) than A308 obeses

Within the DPP study population, common variants in FTO and INSIG2 are nominally associated with quantitative measures of obesity, directly and possibly by interacting with metformin or lifestyle intervention

rs8050136 in FTO
Increased body weight in carriers of the risk allele of FTO SNP rs8050136 is a consequence of increased food intake, but not of impaired energy expenditure tance. In the initial report of the RIVAGE study, some SNPs showed interactions with a metabolic response to diet (through ApoE and LDL-cholesterol and triacylglycerols, apoA-IV and LDL cholesterol, MTP and LDL-cholesterol, intestinal fatty acid-binding protein, and triacylglycerols).

Ethnic specific and region specific responses, possibly related to diet, were shown to be mediated by several SNPs in the human integrin beta 2 subunit (ITGB2) gene, the diacylglycerol acyltransferase (DGAT) gene, as well as thrifty genes FABP", MTP, CAL10, beta 3AR, apo-E, UCP2, UCP3-p, PPARgama2, and LEPR.

None of the abstracts reported on a link between any SNPs and smoking, whereas psychological stress was only mentioned in one article, where it was reported to have been reduced following an 8-week hypocaloric diet.

Studies identified through HuGE Navigator fell in one of three categories, where SNPs were linked with increased body weight and either physical activity, diet characteristics, or some type of a mixed intervention aimed at reducing body weight, which invariably combined modification of both physical activity and dietary habits.

Physical activity extended an exacerbated protective effect on body weight or metabolic events when coupled with several polymorphisms in the BAR-2, FTO, MC4R,
LIPE, GNB3, UCP3, and the PPARG gene. An exception was the ADRA2B gene where, in a Chinese population, the D allele conferred a favourable anthropometric and metabolic profile, especially when combined with lower levels of physical activity.

Some studies found gene-obesity-diet interactions. Carriers of GNB3 C825T seem to feel mental discomfort when fasting, which may explain their increased susceptibility towards increased body weight. The 11391/A allele in the adiponectin gene may protect from weight regain after a low-calorie dietary intervention. A low-calorie diet also seems to be a good choice for carriers of CB1, NPY, 420C $>$ G polymorphisms in the resistin gene: allele carriers had a better response to the dietary regimen in terms of weight loss and metabolic changes, when compared to wild type participants.

In one study, a minor allele in the rs894160 on the PLIN gene was associated with additional weight gain, but only combined with low intake of carbohydrates; when coupled with higher intake of complex carbohydrates, the allele seems to have played a protective role against obesity. Another study found that both carriers of wild type and mutant alleles on the Lys656Asn locus in the LEPR gene lost weight in response to a low-fat, as well as a low-carbohydrate diet. However, only wild type 
carriers had lower leptin concentrations, which was seen with both tested diets.

A hypocaloric diet seems to work well for people with the -55CT polymorphism of the UCP3 gene, whereas having the PPARgamma Pro(12)Ala SNP may confer resistance to a low-calorie diet. On the contrary, the $\mathrm{C}$ allele of the PPARgamma-2-174G $>$ C SNP seems to protect against regain of lost weight, and this effect is further strengthened by the presence of the Ala allele of the PPARgamma-2. Another study found that some CPT1 variants may modify body weight response to fat intake.

Several genotype-by-nutrient interactions were confirmed in a study of 549 obese European women. Although the study tested 42 polymorphisms in 26 candidate genes, the only tests that yielded statistical significance were for the interaction between fiber intake and the $-514 \mathrm{C}>\mathrm{T}$ polymorphism of the LIPC gene, as well as those for fat intake and $-11377 \mathrm{G}>\mathrm{C}$ polymorphism of the ADIPOQ gene and the $-681 \mathrm{C}>\mathrm{G}$ polymorphism of the PPARG3 gene.

Carriers of the minor allele PLIN11482A showed resistance to weight loss after a 1-year low-energy dietary program. Women with APOE4 allele benefit the most from a low-fat, low-cholesterol diet, whereas the lipid profile could worsen in women without the APOE4 allele.

Finally, response to complex interventions that include advice on both diet and physical activity may be hampered or facilitated by various SNPs in the UCP2, UCP3, AGT, LEPR, FABP2, beta(3)AR, TNF-alpha, FTO, and INSIG2 genes.

\section{Discussion}

We have identified in the literature a number of SNPs that may be associated with increased risk for overweight or obesity and also with behavioural risk factors for these traits. With the advent of personalised health care, results of SNP genotyping are likely to start guiding personalised prevention of complex diseases in the near future.

Personalised prevention of obesity may develop twofold: as behaviourally based or pharmacogenomic approaches. Based on our findings, it is imaginable that, for example, carriers of rs1477196 and rs1861868 in the FTO gene would need to be advised to make sure they kept physically active above levels recommended for the general population, as this may protect them from excess weight. Carriers of P129T polymorphism in fatty acid amide hydrolase and carriers of APOA5-1131T $>$ C polymorphism may need to be advised to opt for low-fat diets, whereas low-energy diets may prove a better choice for carriers of ht1 on the UCP-3 gene, carriers of A-3826G, A-1766G, and $\mathrm{G}+1068 \mathrm{~A}$ on the UCP-1 gene, and carriers of $276 \mathrm{G}>\mathrm{T}$ at the ADIPOQ gene. APOA5-1131T $>$ C polymorphism is of particular interest and preventive potential, due to its high prevalence of $13 \%$ in the studied population.

These and most probably other SNPs hold promise for future design of personalised behaviourally based inter- ventions for preventing obesity. However, we are still in the discovery phase of genomics obesity research ${ }^{15}$. Most of the gene-environment-behaviour interactions explored in this paper have only been tested in a single study. Moreover, studies are often poorly described and lack methodological detail necessary for critical appraisal; samples are often small, include healthy volunteers, or no information is given on the selection process; analysis frequently fails to account for multiple testing, and only some studies report the proportion of variance explained by any given gene variant. Indeed, more than half of the obesity related genes in the HuGE Navigator's Phenopedia have only been implicated in a single study thus far. It is likely that many of these associations may be rejected in future replication studies.

We believe now is the time to help obesity genomics on the long road towards effective clinical and public health interventions, not least by developing reporting standards - which are lacking for this field of research. This gap has been somewhat filled while our paper was under review ${ }^{16}$. Some of the included studies reported sufficient information on markers (including i.e. rs code for SNP markers, which are widely accepted unique SNP identifiers), while some reported SNP or other descriptions in a non-standardised way. Results were not always clearly stated, especially in the articles covering gene-obesity-diet interactions.

These issues made us consider and investigate the feasibility of using some of the existing standards. Although a number of relevant attempts have been made, including the GO ontology and several applications that use the XML language, we could not identify any applications that could fit the available data from the included studies, which are commonly reporting a simple association of a genetic marker with some phenotypic trait or a disease.

Given the already large number of studies reporting on gene-obesity-behaviour interactions, an enormous potential for similar future work, as well as the relevance of this line of research for population health, it would seem prudent to consider developing a specific reporting standard for these studies. At the very least, following the reporting practice developed for other study designs (e.g. CONSORT for clinical trials), we would argue in favour of stating the study design as part of the title, as well as introducing a structured abstract that would include the information on a unique SNP identifier (rs code), effect allele, physical SNP location (usually defined as the number of base pairs from the chromosome start), chromosome, gene name, analysed trait, information on possible effect modifiers (i.e., adjustment for age and sex, other confounders, multivariate methods), proportion of variance, and other information. The application and use of such structured reporting format would likely enable creation of more informative, perhaps even entirely computer-generated summary reports. Establishing a vocabulary consensus in describing elements of study and data, for the purpose of annotation and integration, would also be a valuable contribution to the field. 
As we contemplate what effects genetic testing, once widely available, might have on people's motivation to lose weight or the public's readiness to accept the new realities or, indeed, what new types of obesity might soon become definable in the disease categorisation of the genomic era, some improvement in the scientific communication to help us get there faster seems advisable. This seems in tune with views of others previously expressed in this journal ${ }^{17}$.

\section{Strengths and limitations}

We have conducted a comprehensive search across multiple databases and present in one place current state of the evidence relevant to the development of future behaviourally based obesity prevention strategies. However, we did not hand search the references in the included articles and it is possible that some published studies escaped our search strategy. Furthermore, we did not perform a formal assessment of the quality of the included studies, as we felt this was beyond the scope of the paper. Finally, we have not attempted to synthesise the findings at this stage, due to the heterogeneity of the included studies.

\section{R E F E R E N C E S}

1. AMERICAN HEART ASSOCIATION, The Americas, accessed 12 06.2010. Available from: URL: http://www.americanheart.org/presenter.jhtml?identifier $=2575 .-2$. BRITISH HEART FOUNDATION, Total CVD mortality in Europe, accessed 12.07.2009. Available from: URL: http://www.heartstats.org/datapage.asp?id=754. - 3. WORLD HEALTH ORGANIZATION, accessed 12.05.2010. Available from: URL: http://www who.int/dietphysicalactivity/publications/facts/cvd/en/. - 4. AMERICAN HEART ASSOCIATION. Circulation, 106 (2002) 388-91. — 5. AMERICAN COLLEGE OF CARDIOLOGY/AMERICAN HEART ASSOCIATION TASK FORCE. Circulation, 113 (2006) 2363-72. - 6. CARGILL M, ALTSHULER D, IRELAND J, SKLAR P, ARDLIE K, PATIL N, Nat Genet, 22 (1999) 231-8. - 7. MUSIĆ MILANOVIĆ S, IVIČEVIĆ UHERNIK A, FIŠTER K. Coll Antropol, 33 (Suppl 1) (2009) 67-73. - 8. CLEMENT K, SORENSEN TI, Obesity: genomics and postgenomics (Informa HealthCare, 2007). - 9. EXPERT PANEL ON THE IDENTIFICATION, EVALUATION,

\section{Conclusions}

Personalisation of behaviourally based preventive approaches against obesity seems feasible in the near future. Automation of search algorithms, as well as development of more efficient tools for knowledge synthesis of genomic research into gene-obesity-behaviour interactions might facilitate the advent of widely available personalised prevention strategies. As a small step forward, we propose that structured standards of reporting specific to the field be developed as soon as possible, so as not to unnecessarily delay translation of these burgeoning findings into clinical and public health practice. In addition, our future efforts shall concentrate on developing a research repository dedicated to the use of public health genomics for obesity control.

\section{Acknowledgements}

This research was supported by the European Commission (Project Reference: 224176) and by the Croatian Ministry of Science, Education and Sport (Project Number: 108-1080135-0264).

\section{K. Fišter}

University of Zagreb, School of Medicine, „Andrija Štampar « School of Public Health, Rockefellerova 4, 10000 Zagreb, Croatia

e-mail:kfister@snz.hr

\section{UTIRANJE PUTA ZA PERSONALIZIRANU PONAŠAJNU PREVENCIJU PRETILOSTI: SUSTAVNA PRETRAGA LITERATURE}

\section{S A Ž E T A K}

Cilj ovog rada bio je identificirati polimorfizme jednog nukleotida (SNP, od engl. single nucleotide polymorphism) koji bi mogli odrediti interindividualne razlike u odgovoru, u smislu promjene tjelesne težine, na pojedine ponašajne čimbenike rizika za prekomjernu debljinu ili pretilost, stoga otvarajući mogućnosti za personalizirane ponašajne preventivne intervencije. U bibliografskim bazama, bez jezičnih restrikcija, identificirali smo radove koji su izvještavali o 
povezanosti pojedinih SNP-ova s prekomjernom debljinom ili pretilošću kao i s ponašajnim rizičnim čimbenicima za razvoj ovih značajki. Identificirali smo 64 genske varijante koje bi mogle biti uključene u interakcije gen-pretilost-ponašanje. Temeljem ovih rezultata moguće je zamisliti razvoj personaliziranog savjetovanja o promjeni životnih navika, s ciljem smanjena tjelesne težine, međutim genomika pretilosti još je u ranoj translacijskoj fazi; potrebna je replikacija rezultata u brojnim budućim istraživanjima prije no što ovi u velikoj mjeri pionirski rezultati unaprijede kliničku i javnozdravstvenu praksu. U kvaliteti istraživanja kao i izvještavanja o njima ima mnogo prostora za poboljšanja. Zaključujemo da je personalizacija ponašajnih preventivnih intervencija protiv pretilosti izvediva no automatizacija pretraživačkih algoritama i razvoj učinkovitijih metoda sinteze znanja generiranih u genomskim istraživanjima mogli bi ubrzati translaciju prema širokoj dostupnosti personaliziranih preventivnih pristupa. Naša će buduća nastojanja stoga uključivati razvoj takvih metoda i oruđa, kao i razvoj repozitorija istraživanja posvećenog uporabi javnozdravstvene genomike u kontroli pretilosti. 